\title{
Branded Food Commodities: A Study of the Egyptian Commodity Products
}

\author{
Marwa Elgebali ${ }^{1}$ \\ ${ }^{1}$ School of Business and Finance, Newgiza University, Cairo, Egypt \\ Correspondence: Marwa Elgebali, School of Business and Finance, Newgiza University, NEWGIZA, KM 22 \\ Cairo-Alex Road, Giza, 12256. Egypt. E-mail: marwa.elgebali@ngu.edu.eg
}

Received: May 2, 2019 Accepted: May 23, 2019 Online Published: July 12, 2019

doi:10.5539/ijms.v11n3p49 URL: https://doi.org/10.5539/ijms.v11n3p49

\begin{abstract}
Purpose: The study explored the attitudes and brand awareness of consumers towards purchasing branded food products. Moreover, the factors that influence the consumers' decisions while purchasing the chosen branded commodities foods products have been investigated.
\end{abstract}

Methodology: The study used a sample of 200 participants acquired from diverse cities within Egypt, while the selected products comprised branded sugar and rice. The study used variance analysis of participant's attitudes and buying intentions.

Findings: It was revealed that consumers' awareness when purchasing the branded rice and sugar, originates from the relatives, friends, and reference groups. It also comes from the point-of-sales promotion and recommendations from the retailers and sellers. Concerning the consumers' perceptions, it was revealed that they consider branded sugar and rice as safe from harmful chemicals such as insecticides and pesticides, as well as adulterants. On the same note, the customers perceive that buying marked rice and sugar is a sign of high social status. Regarding the factors that influence the buying decisions, it was revealed that flavor, safety from adulterants or harmful chemicals, and aroma are the primary factors that consumers consider.

Study Limitations: Based on validity constraints, the further study with a broader sample size was proposed. The further research should focus on the link between brand equity and the branded commodity goods.

Practical impacts of the study: Retailers and product marketers should focus on creating brand awareness which is the primary concern for the consumers. Similarly, the marketers should formulate strategies targeting the different consumers' demographics-based market segments.

Value/originality: this research is unique since it aims to investigate the consumers' purchase behavior for commodity goods, especially the branded food products, which other studies have not assessed. Additionally, limited researchers have focused on investing the consumers' attitude and brand awareness with respect to the branded food products in developing countries such as Egypt. In formulating marketing strategies of such products managers need to understand how consumers evaluate and what kind of attitudes they hold towards it.

Keywords: Egypt, purchase behavior, brands, brand awareness, commodity food products, consumer behavior

\section{Introduction}

Egypt is a leading market with highest economic diversification in the Arab world. The country's demographic trends are anticipated to grow in the coming years and enhance spending, which in turn, contributes to economic growth. Despite the possible inflationary forces that may slow the growth, Egypt will still experience an overall increase in purchasing power over the years (Wang, 2019). In this regard, the growth in purchasing power will influence consumption of branded imported food commodities. The report by GAIN (2017) cites the Economist Intelligence Unit for revealing that in 2016, the sales of tobacco and beverage reached nearly $\$ 92$ billion, which is equivalent to almost $\$ 999$ per capita, while that of food products in 2015 was nearly $\$ 70$ billion. On the same note, the sales forecast for tobacco and beverage revealed an increase in sales to $\$ 144$ billion, while sales of food products will be nearly $\$ 98$ billion in 2020 (GAIN, 2017).

The retail food sales data obtained from the supermarkets, traditional groceries and stores revealed that the total value of food products sales was nearly EGP 226 billion in 2016; which represented an 11\% increase from the 
sales in 2015, according to the report. On the other hand, the private sector predictions projected a proportionate growth in 2017, expressed by sales of nearly EGP 250 billion. Nevertheless, in 2016 the sales in dollar-terms were forced down by devaluation while that of nominal terms remained steady. Egypt is also experiencing a steady growth of modern hypermarkets and supermarkets, whereby in 2016, the country had nearly 1,252 supermarkets and hypermarkets outlets. On the same note, Egypt had approximately 115,041 traditional market outlets, which significantly outnumbered the modern sales platforms (GAIN, 2017).

It is also essential to note that in 2018, Egypt's top two retailers were new companies in the market, implying that growth is a vital objective of each firm. The Kazyon stores and Turkish BIM chain were the leading retailers that have already recorded significant increase since establishment. Kazyon was founded in 2014 with one store, which by 2017 had expanded into nearly 182 subsidiaries in 14 governorates. Turkish BIM, on the other hand, was established in 2013 with only 43 outlets, which increased to almost 256 subsidiaries in 11 counties as of August 2017. Despite the significant growth over the short period, these two main retailers have strategic plans to expand further into all the Egyptian governorates and market segments.

\section{Objectives of the Study}

1) Are the consumers aware of the branded sugar and branded rice? If yes, what are sources of the awareness?

2) What features of the branded sugar and rice are most essential to the consumers?

3) What major factors influence the buying of branded sugar and rice among the consumers?

4) Are these factors affecting the purchase of branded sugar and rice classified based on demographics?

5) Are the consumers' perceptions towards the essential features of banded commodity products different?

\section{Literature Review}

\subsection{Branded Food Products}

The demand for high-quality products at premium prices is rising due to the growing concerns for health, changing lifestyles, and increasing incomes. Moreover, the time scarcity and growth of international corporations in the food industry are not only influencing the demand for quality foods and premium pricing but also influencing the customer buying behavior (Javed \& Javed, 2015). Conversely, over the past ten years, the modern kitchen lifestyle is gradually replacing the traditional kitchen system, which arises from the emerging nuclear families and modern lifestyles. Despite the shortage of time, consumers are becoming more concerned by attaining the nourishment. These factors collectively impact the demand for branded food products, which meets the consumers' preferences of the improving lifestyles. For instance, customers consider the branded products to have excellent hygiene, high quality, convenient location in a single store, and value for money (Wolff, 2015). Therefore, branded products such as flour, rice, peas, frozen French fries, and meat are experiencing growing demand regardless of the high pricing.

The increasing globalization also influences the faster price discovery for products, reduced investment and trade barriers as well as improvement in transport and telecommunications technologies. Moreover, the price wars have enhanced amidst the declining profit margins for the commodity products (Muellera, 2010). Consequently, large companies implement the product branding strategy to overcome the price traps that exist in the commodity markets for products such as wheat flour, milk, rice, edible oil, and spices. Therefore, the product branding is applied as a differentiation strategy for overcoming the price trap and increasing the profits.

One of the primary objectives of businesses is to achieve sustainable competitive advantages, which includes product differentiation to create uniqueness. Considering the rising uncertainty in the corporate world achieving sustainable competiveness is important not only for managers but for companies as well (Liu, 2019). The food sector is characterized by commoditization, whereby companies' products and services have similarities on price, features, and quantities. As a result, firms engage in differentiation to overcome commoditization and present different values that attract consumers and overcome the commodity trap of prices and volume. The best approach for product differentiation is branding; distinguishing company's products using a unique brand name and other features (Yan, 2010). The marketers in the current competitive business environment must strive to differentiate the products and evade the general consideration as commodities (Yan, 2010). According to Aaker (1996b), a brand is any different symbol and/or name including trademark, logo, or packaging used in identifying the good or service from a seller or company and creates uniqueness from other similar products. Since it is unique to every firm or product, consumers link each brand to specific features, product quality, usage, or logo (Anderson, 1983). Additionally, the brands create a unique product dimension that sellers may exploit to set exceptional prices (Kotler, 1994). 
The brands have a direct relationship with customers' feelings, thoughts, attributes, awareness, attitudes, benefits, and experiences (Montgomery \& Wernerfelt, 1992). The businesses, on the other hand, develop brands that possess the emotional, symbolic, experimental, and functional advantages of consumers (Ghodeswar, 2008). In this regard, the functional benefits incite the buyers to seek the product to satisfy problems related to consumption, while the symbolic benefits stimulate internal needs such as social status or class, self-esteem, ego, role position, or group membership (Ghodeswar, 2008). The experimental benefits stimulate sensory pleasure or cognitive stimulation that the consumer gains from the brand (Park et al., 1986). In most cases, the businesses tend to incorporate all the three benefits to meet the diverse demands of the different customers (Ghodeswar, 2008).

According to Hankinson (1995), branding refers to distinguishing the product or service based on personality and position, with respect to the competitor. In this case, they argued that the personality contains the symbolic and functional attributes while positioning contains the distinctive features. Aaker (1996b) also supported that consumers are currently concerned with emotional and functional benefits of the brand as opposed to the quality. The customer-based brand equity score for a product is essential when formulating and setting prices (Lassar et al., 1995). The customer-based brand equity was measured using a scale of performance, social image, commitment, trustworthiness, and value. The test revealed that brands with higher scores on the customer-based brand equity were priced higher than those with low scores. Therefore, the brand position is crucial in setting premium pricing that also enhances customer satisfaction based on the five elements in the customer-based brand equity scale (Lin, 2015).

\subsection{Commodity Products Branding}

Dissimilarly to other kinds of goods and services, commodity products are highly undifferentiated. For instance, wheat flour, rice, or sugar is a similar product in all markets except for the branding and slight modifications made during processing. Moreover, consumers have a higher demand for natural commodity goods without chemical composition or changes, which is evident in the severe attempts made by manufacturers to offer natural products (Chernatony, 1996). In this regard, the primary question is why branding is vital for highly undifferentiated commodity goods. According to Keller (2003) and Kapferer (1997), the consumers prefer recognized brands to prohibit the perceived risk of bad choices. The proposed that customers value their health and would not risk consuming products from unrecognized brands; which explains why the majority of food products in Europe are sold through brands. Furthermore, the customer loyalty is directly linked to trust, which is only gained through brand with differentiating features (Lau \& Lee, 2000).

The commodity manufacturers and sellers, on the other hand, apply branding to differentiate the products and apply premium pricing (Dolak, 2005). Here it should be noted that in developing countries like Egypt, the organizations do not look enough at customer's feedback and not giving enough attention to their perceptions and expectations (Ilyas \& Javed, 2018). Powerful brands can help bride this gap. Thus, the creation of powerful brands adds value and product differentiation, which leads to price inelasticity. In this regard, commodity products branding is a way of enhancing customer awareness, loyalty, and stimulating the willingness to pay the premium prices (Mohan, 2013). In the case of Egypt, the total rice market in the country forecasted consumption of 4 MMT (million metric tons), down by 400,000 metric tons (MT) from the MY 2017/18 estimate. Egypt's MY 2018/19 rice imports are forecast at 200,000 MT, to compensate for an anticipated reduction in local rice production (USDA, 2018). In the recent years, the sales of branded rice in the domestic market are growing at $15 \%$ and $25 \%$ in the international market.

In Egypt the domestic consumption for sugar, in MY 2017/18 reached 3.050 MMT a rise of 3.4\% of previous year. FAS Cairo attributes this increase to the annual increase of population. Additionally, Egyptians are expected increase their sugar consumption to meet caloric needs, substituting sugar for other key commodities, such as poultry and beef, due recent food inflation (GAIN, 2017).

AlOsra, Doha and Elsafwa are some of the leading sugar brands in Egypt that hold the highest market shares. Based on this information, the consumers have specific awareness towards branded commodity products; it influences their decisions towards purchase frequency, size, and perception. Therefore, this study will investigate the consumers' awareness towards branded products and the outcomes on purchase intention and attitude.

According to Yeung and Morris (2001), assessing the customers' intention and attitude for a brand is essential in determining the appropriate psychological features for the product. Moreover, the purchasing behavior is influenced by the perceived brand quality, packaging, and other economic factors (Fraquhar, 1991; Aaker, 1996; Dyson et al., 1996; keller, 1993; Ailawadi, 2003; Alam \& Sayuti, 2011). However, despite the large studies on the consumers' attitudes and purchase intentions towards commodity products, little information exists regarding 
their attitudes and perceptions for branded food products. Therefore, this research fills the gap, reveals detailed information, and formulates recommendations for the relevant stakeholders in the branded food products industry.

\section{Objectives of the Study}

i Are the consumers aware of the branded sugar and branded rice? If yes, what are sources of the awareness?

ii What features of the branded sugar and rice are most essential to the consumers?

iii What major factors influence the buying of branded sugar and rice among the consumers?

iv Are these factors affecting the purchase of branded sugar and rice classified based on demographics?

$\mathrm{v}$ Are the consumers' perceptions towards the essential features of banded commodity products different?

\section{Research Methodology}

The study population was derived from the five major cities with the highest consumption rate of rice and sugar in Egypt. The towns comprised Cairo, Alexandria, Mansoura, Luxor, and El-Mahalla El-Kubra. The population of the study included 300 participants acquired through judgmental sampling based on convenience but equally from all the cities. The data was collected through quantitative design whereby numerical information was gathered using questionnaires. Further, data analysis was conducted through standard deviation, mean score, and variance analysis. The surveys contained questions with variables including brand price, attractiveness, image, availability, packaging, retailer's recommendation, availability of brand information, and relatives'/friends' recommendations. Additionally, the participants were tasked with rating the attributes using Likert-scale whereby one means least important while five is for the most important. The data analysis assumed a significance level of $\mathrm{p}<0.05$ and mean population for rating scale as 3 .

\section{Measures}

Based on the previous research, different parameters were developed for the analysis of consumers' attitudes and other factors affecting the buying of branded commodity goods. Some of the previous studies include Smith and Wright, 2004; Watanabe et al., 1999; Jang et al., 2005; Grunert et al., 2000; Cerjak et al., 2011; Felzensztein et al., 2004; Tsiotsou, 2006; Lodorfos and Dennis, 2008; Utami, 2010; Ceylan, 2010, Wang, 2010; and others. Tsitsou (2006) postulates that the consumers' purchase intentions are directly linked to the perceptions towards brand quality adding later that the perceived brand quality could have direct and indirect impacts on the consumers' buying intentions. Furthermore, the purchase intentions could be influenced by the value for money and price of the branded product (Wang et al., 2010). In this regard, customers are more attracted towards goods they consider to have the highest value, which producers always strive to differentiate and maximize (Smith \& Wright, 2004). In summary, products with reasonable pricing are economical and thus enhance the value for money (Orth et al., 2004). However, branded products with high prices with respect to the benefits are considered to have a low-value proposition; which leads to poor perception, low demand and reduced sales (Tikkanen \& Vaariskoski, 2010). For instance, the pricing perception had a negative influence on consumers' decision to buy Malang meatballs (Utamu, 2010); which implies that higher prices equal reducing quantity of food products sold (Bareham, 1995 cited in Utami, 2010).

In the consumers' position, a quality product should have the following characteristics: convenience, packaging, availability, variety, cleanliness, price, freshness, and choice. The combination of these features influences the buying decision (Silayoi \& Speece, 2004; Juric \& Worsley, 1998). However, out of these qualities, customers may focus more on a particular attribute depending on the demographics and personal decision. According to Deodhar and Intodia (2001), consumers may focus on flavor as the dominant attribute in the case of branded ghee. Espejel et al. (2008) also proved that proper and positive satisfaction of the perceived dominant trait results in customer loyalty and satisfaction. In similar research conducted by

Hogg and Kalafatis (1992) it was revealed that consumers do not focus on low prices when buying branded rice. However, they consider the quality, marketing activities, country of origin, and cost as the primary factors when purchasing the branded rice.

According to Akgungor et al. (2010), the four parameters that customers value when buying branded food product include quality, knowledge of production method (certified), price, and health risks. In this regard, quality pertains to the taste, hygiene, nutritional value, and cosmetic condition. The consumers' buying decision is also influenced by features including hedonic, convenience, process, and health-related features (Grunert et al., 2000). In this regard, the hedonic attributes are associated with the smell, taste, and the brand appearance. Health attributes are connected with the positive impacts on consumers' well-being. Process attributes are related to 
safety and quality of the production process. Lastly, convenience attributes are linked with the effort and time taken to buy, prepare, store, and consume the product (Cerjak et al., 2011). According to Ali et al. (2010), consumer buying food products are highly concerned by the cleanliness/freshness before quality, price, packaging, variety, and availability. On the same note, the choice of buying food product is influenced by the consumers' perception of health risk and nutritional value (Akgungor et al., 2010).

The two dependent variables for this study are consumer's attitudes and consumer's perceptions. To measure consumer's attitudes the following independent variables were used; Point-of-purchase display, retailer recommendation, friends and relatives, advertisements, newspapers/magazines, promotional Campaigns. The alpha coefficient for the six items is .849 , suggesting that the items have relatively high internal consistency. To measure consumer's perceptions the following independent variables were used; more nutritious than unbranded rice, better taste/flavor than unbranded rice, free from adulterants, a quality certified products, social status, price, pesticides and chemicals, closeness, packaging. The alpha coefficient for the nine items is .826 , suggesting that the items have relatively high internal consistency.

\section{Results and Discussion}

This chapter entails analysis of the participants' profile including age, occupation, income, gender, and location. According to the findings presented in Table 1, the age groups of the participants were as follows; 31 percent of the participants were $18-15$ years old, 36 percent were $25-40$ years old, while nearly 32 percent were above 40 years old. Considering the gender variation, 54 percent and 46 percent of the participants were males and females respectively. Based on occupation, 29 percent were businesspersons, 29 percent had no occupation and were mostly housewives, the other 26 percent were employed in the service industry, and 8 percent were still students. The education data revealed that the majority had not attained graduate degrees with only 14 percent being post-graduates and 3 percent graduates.

\subsection{Brand Awareness and Brand Recall}

The primary research question in this section was whether the participants had awareness for branded sugar and rice. It was revealed that 180 out of the 200 participants were aware of the branded rice. On this note, $98 \%$ of the respondents with high income $\left(\mathrm{I}_{1}\right)$ and $74 \%$ with low income $\left(\mathrm{I}_{3}\right)$ had awareness for branded rice. Concerning branded sugar, $51 \%(\mathrm{n}=103)$ of the total participants were informed of the product. Similarly, $71 \%$ of the participants with a high-income group $\left(\mathrm{I}_{1}\right)$ had awareness for branded sugar, while only $26 \%$ of the low-income participants (I3) were aware of the same product. The majority (54\%) of the participants with average income (I2) had information about the branded sugar.

The study applied the brand recall approach to measuring the extent of brand awareness. In this case, the participants were tasked with naming at least three brands of rice that they could recall or knew. Brand awareness influences the consumers' attitudes and perceptions as well as motivating brand loyalty and choice. In the customer's point-of-view, brand awareness is an exact reflection of the brand salience, which controls the purchase decision (Aaker, 1996). It was also revealed that consumers have varied awareness levels as evident in desperate brand knowledge, recognition, top-of-mind, recall, brand opinion, and brand dominance. In this regard, the awareness for new brands was recognition while that for well-known brands was recall, dominance, or information. The study also revealed that $54 \%$ of participates could recall 2-3 brands of rice including Eldoha, Elsaa rice, Elsuhagy rice, and N1. Conversely, 27\% could not recall any brands of rice despite being aware of the existence of branded rice in the market; symbolizing that a significant number of marketers have failed to develop strong brand awareness. Further, more participants with higher income (I1) could recall brands of rice more than those with low income (I3).

The findings on branded sugar were different from those on rice. In this case, only 22 percent of the participants aware of the branded sugar could recall one or more brands while $77 \%$ could not remember any brand. Moreover, participants in the high and middle-income groups (I1 and I2) could recall the brands of sugar more than those in the low-income group. For instance, Elosra, Eldoha, and Elsafwa were the most recalled sugar brands. Based on these findings, the marketers of branded sugar are focusing more on the consumer demographics with mid-upper income levels.

\subsection{Sources of Awareness}

Based on the findings summarized in Table 2, the participants attained the awareness for branded sugar and rice through friends/relatives, retailers' recommendations, and point-of-purchase display, as the primary sources. The information was obtained through instructing the participants to rank the sources of brand awareness based on 
the scale of importance. In this regard, the majority of the participants rated friends and relatives as the primary source of brand information and awareness.

\subsection{Attitudes Towards Branded Food Products}

Kotler (2000) defined attitude as the predisposition to behave towards an object unfavorably or favorably consistently. The expectancy-value theory added that attitude arises from the product of belief and evaluation (Ajzen \& Fishbein, 2008). The attitude (a) of a consumer originates from the beliefs (b) towards the features of the product, multiplied by the personal assessment or evaluation (e) of those attributes; thus $A=\Sigma$ biei (Ajzen, 1991). However, according to Ajzen (2001), the review of the product attributes is directly associated with the cognitive abilities of the person. In this regard, customers with high cognition have higher abilities to evaluate a product based on the features and then integrated the beliefs to develop an attitude towards the brand.

In the study, participants were tasked with indicating the degree of agreement/disagreement with different variables of branded sugar/rice. The measurement scale was calibrated in strongly agree as +2 , agree as +1 , indifferent as 0 , disagree as -1 , and strongly disagree as -2 . The parameters provided in a questionnaire included pesticides-free, harmful chemicals-free, adulterants-free, social status, certified product quality, better taste/flavor, easy availability, and nutrition. In the case of branded rice, the participants stated that consuming branded sugar and rice promotes their social status. The highest expected results were that consumers considered taste and quality/price as the primary attributes for purchasing branded products; according to (Urban, 2012) .It was revealed that the majority of the participants strongly agreed that branded sugar and rice are free from insecticides, harmful chemicals or adulterants; which implied that they possessed strong attitude towards branded sugar and rice due to quality.

Based on pricing, the high income (I1) respondents were satisfied with the pricing while those in low-income groups considered branded sugar and rice as overpriced. Nevertheless, the study revealed that consumers have positive attitudes towards the branded sugar and rice but negative towards barriers on price and income limit consumption. Dean et al. (2008) argued that customers' behavior is not only assessed based on costs and benefits but also on favorable and unfavorable feelings created. The argument was supported by Noor (2016) who revealed the existence of a strong affirmative relationship between attitudes and intention towards buying organic food products. The research findings also opposed the assumption that certain types of packaging preserve taste/flavor and are easy to handle; which was evident in the majority of respondents who strongly agreed on packaging as an essential attribute for branded sugar and rice. Participants in the low-income category strongly disagreed that the standard $5 \mathrm{~kg}$ packaging is unsuitable. As summarized in Table 3 , the unfavorable attitude of low-income participants towards packaging could be caused by insufficient storage space and limited disposable income for purchasing the "overpriced" branded rice and sugar.

H01: a significant difference does not exist between the perceptions of different consumer demographics regarding the significance of various branded rice and sugar parameters.

In the study, variance analysis was applied to determine the existence of significant differences in attitude of different demographics towards the branded sugar and branded rice. The analysis involved comparison of the responses provided by participants of different age, education, income, and gender; on various parameters of the branded products. As illustrated in Tables 4 and 5, the findings show that there is a significant difference in the responses towards parameters such as price, packaging, availability, and health safety. In the education segment, graduates and postgraduates responded that branded sugar and rice are overpriced and not readily available to the local homes. Conversely, participants with education levels below graduate and higher secondary strongly disagreed that packaging of the branded sugar and rice is easy to handle.

In Egypt, the standard packaging for the branded sugar and branded rice is $5 \mathrm{kgs}$, which is challenging to preserve. However, as significant difference still existed in the males' and females' responses regarding the difficulty in handling and storing the packaged branded rice and sugar despite both disagreeing. The same significant difference also existed in the reactions of participants in diverse education groups; some disagreed while others strongly disagreed with the parameters that branded rice are easily available near homes, overpriced, and promotes social status. In the income category, a statistically significant difference occurred on the attitude towards better nutrition, taste/flavor, certified quality and safety from adulterants parameters. Besides, the income categories also differed in perception towards easy availability, easy-to-handle packaging, and safety from pesticides/insecticides parameters of the branded rice. However, the participants in income category agreed that the consumption of branded sugar and rice promotes their social status. Therefore, $\mathrm{H} 01$ is partially true since significant differences exist in the attitudes and perception of customers of different income, education, and gender, towards the branded commodity products. 


\subsection{Purchasing Marked Sugar and Marked Rice}

The questionnaire included questions regarding the buying of the branded products, the frequency of purchase, the preferred packaging size, and the issues affecting the purchase decision. The study revealed that $66 \%$ of the participants with awareness $(n=180)$ of the branded commodity products purchased branded sugar and rice. The findings support the argument that income does influence the buying decision of branded sugar and branded rice. Similarly, the results fill the research gaps of Vermeir and Verbeke (2008) and Chen (2009), who argued that a discrepancy exists between consumers' marketplace behavior and attitude; and the variation is caused by inequalities in income and awareness.

Concerning branded rice, $75 \%$ of the respondents strongly agreed with the $5 \mathrm{~kg}$ packaging, while nearly $19 \%$ preferred the $1 \mathrm{~kg}$ packaging. In this case, $75 \%$ of the participants in higher income group (I1) strongly agreed with the $5 \mathrm{~kg}$ package while $83 \%$ of those in low income (I3) strongly agreed with the $1 \mathrm{~kg}$ pack. Regarding branded sugar, $94 \%$ of the participants prefer the $5 \mathrm{~kg}$ package; in this case, $90 \%$ of respondents in higher income category (I1) strongly agreed with the larger $5 \mathrm{~kg}$ packaging. It was also revealed that $70 \%$ of the participants buy sufficient amount of branded rice once monthly, while nearly $24 \%$ purchase the product on special events or occasions. On the other hand, $92 \%$ of the participants purchase sufficient amount of branded sugar once monthly. Moreover, most consumers of branded sugar and rice buy the commodities in bulk, mostly once in a month. Further, the majority of those customers buying marked rice and sugar are in higher income groups, but they still like discounts.

\subsection{Issues Influencing Buying Marked Sugar and Marked Rice}

The questionnaire contained different questions requiring the respondent to rate the various factors affecting their buying decisions for branded sugar and rice. The Likert-Scale rating was applied as illustrated in Table 6.

According to Aaker (1996b), the value proposition of the brand is the pillar of the brand-as-product perspective. In most cases, the functional benefit of the brand is the primary source of the value proposition, which customers consider. Aaker (1996) also proposed that brand value is determined through questions on whether it provides value for money and the reason to buy the brand over the competitors. In this study, the respondents stated that the factors influencing their purchase decisions include the value for money, the recommendations from relatives/friends, easy availability, price, and brand image. In the lower income category, the respondents were concerned about value for money and price more than their counterparts in the higher income groups.

According to Johnson et al. (2001); Johnson and Gustaffson (2000), the price is a primary driver in customers' satisfaction and brand loyalty. In the case of branding, price premium - the price customers are willing to pay is an essential variable playing a significant contribution to the financial equity of the brand (Roland, 2000). However, according to Chen (2009), the premium prices as a barrier to buying can be reduced through enhancing brand awareness and justification for the high pricing. In this regard, Rimal et al. (2001); Chen (2009) proposed that explaining the reasons for the higher prices could eliminate the barrier it creates in hindering most consumers from buying the product. In addition to price, it was revealed that other factors influencing the buying decisions include the brand image, availability, the safety from adulterants and harmful chemicals, references from friends/relatives, and taste/flavor.

H02: a significant difference does not exist in the perceptions of different demographics towards the crucial factors influencing their purchase decisions for branded rice and sugar.

The variance analysis summarized in Tables 7 and 8 , show that lower-income consumers' buying decisions are influenced by price and value for money, while those in higher income consider the brand image, retailers' recommendation, and easy availability, as the primary influences. Those with higher education regard the brand image, as opposed to recommendations from friends/relative/retailers, as the main factors influencing their decision to buy branded rice (Chabiri et al., 2009). According to the research findings on European Community, quality, healthy diet, taste, habits, and family preferences are the main factors influencing food choice as well as education level and income (Vabo, 2014). In this study, it was revealed that taste, safety from adulterants and harmful chemicals, and nutrition are the crucial parameters having an impact on the purchase decision for branded sugar and rice; which is shown in Table 9.

\section{Conclusions and Managerial Implications}

In the Egyptian market, the idea of the branding of commodity products is new, and limited information is available. Consequently, this research was performed to understand the consumers' perceptions and brand awareness towards branded sugar and branded rice. The findings could enhance the knowledge of factors influencing the buying decisions for the branded products; which is essential for marketers. The study revealed 
that $90 \%$ and $51 \%$ of the participants had brand awareness for branded rice and branded sugar respectively. Moreover, those with higher income were more aware of branded products as compared to those in a lower income group. The major sources of brand awareness included the point-of-sales display, references from friends/relatives, and retailers' recommendations. The parameters that customers perceive as the main features of branded rice and sugar include better taste/flavor, safety from adulterants and harmful chemicals, promotion of social status, high nutrition, and certified quality.

A higher percentage of the participants prefer buying the $5 \mathrm{~kg}$ package in bulk, mostly once a month. The factors influencing their decisions include price, value for money, aroma/taste, brand image, references from friends/relatives, and safety from harmful chemicals. Based on these findings, the marketers should strive to enhance the brand awareness and recall amongst the customers. Since references from friends/relatives are significant sources of awareness, the marketers should also focus more on word-of-mouth marketing, which targets the friends and relatives. Since nutrition and packaging also influence buying, the branding should entail sufficient information on nutrition, safety from harmful chemicals, and recipe. According to Zeithaml (1988), consumers perceive that aggressively advertised brands have higher quality as compared to those less advertised. Similarly, since advertising promotes brand familiarity, marketers should highlight the features of informative, attractiveness, and packaging in their advert messages (Markovina et al., 2011).

Worth of an entity (individual, company or brand) is determined by the quality and quantity of its products and services (Sifeng \& Saad, 2018). Concerning the quality of branded rice, the majority of the respondents considered aroma/taste, safety from harmful chemicals, and absence of adulterants as the main factors affecting their buying decision. In this regard, it is recommended that marketers focus on enhancing the quality parameters. According to Ali et al. (2010), consumers have a significant rating for freshness/cleanliness as the essential product attributes for commodity goods. On the other hand, McNeill and Wyeth (2011) argued that customers were more concerned about the product's quality and packaging as compared to price differences of the branded commodity products. Schiffman and Kanuk (2007) revealed that consumers' perception of the price as either, high, fair, or low; plays a significant role in the buying decisions. Hatirli et al. (2004) cited in Ates and Ceylan (2010) also supported that the price variations between processed and unpacked milk significantly influence the household buying choices.

It was also revealed that low-income consumers consider price as a critical factor when buying branded sugar and rice. Consequently, marketers should identify the customers based on income and then differentiate the branded products to meet the demands of diverse clients including those with low income. According to Lin (2015), consumers decrease the percentage of expenditure allocated to highly ranked products as the price increases; which implies that customers may consider the second and third options as price rises. The majority of the companies have also resolved to differentiation and creating smaller and cheaper packages that target consumers with low income (Mohan et al., 2013). The study also revealed that brand image is crucial in influencing the buying decision of customers in higher income category. Consumers with higher income value the branded levels and packaging information on commodity products including cheese, sugar, rice, milk, and flour (McNeill \& Wyeth, 2011). The finding is supported by Kapferer (1997); Aaker (1996a) who revealed that brands that meet the customers' emotional and functional expectations influence trust and loyalty. Moreover, the consumers' trust lowers the perception of the risk of consuming the branded commodity product (Feldwick, 2002). Therefore, marketers are recommended to focus on creating strong and positive brand image comprised of utilitarian and hedonic attributes (Dhar \& Wertenbroch, 2000).

The study also revealed that the availability of the branded sugar and rice influences the buying decisions. In this regard, marketers should focus on availing their branded food products in nearby and accessible stores, retailers, supermarkets, and rural areas; which would fulfill the demands of the majority of consumers who prefer convenience. As competition rises, companies have initiated price wars with the efforts to earn competitive advantages to overcome the declining profit margin and market shares. As a result, firms diversify into targeting the rural market and low-income segments. Therefore, marketers of food products should focus on providing locally relevant and pocket-friendly goods, which still present high value for money.

The study investigated the parameters that influence consumers' attitude and buying decisions for branded commodity products such as rice and sugar. Similarly, to other economies, Egypt is experiencing socio-economic changes that impact the increasing demand for branded products considered to have high value for money and quality. Companies engage in branding to satisfy the changing consumers' expectations; the findings from this study offer detailed information that businesses should implement to enhance customers satisfaction, competitive advantage, and sales revenue. Nevertheless, further study is necessary to investigate the correlation between purchasing branded commodity food products and the attitude parameters. On the same note, 
further research is required to understand the role of sale promotion, advertising, and brand image on the consumers' purchase decisions for branded commodity food products. The study should also be undertaken on the relationship between buying behavior for retail (store) and national brands of commodities.

Table 1. Participants' demographics $(=200)$

\begin{tabular}{lll}
\hline Characteristics/category & Total & $\mathbf{\%}$ \\
\hline Age & & \\
$18-25$ & 63 & 31.50 \\
$25-40$ & 72 & 36.00 \\
$>40$ & 75 & 32.50 \\
Gender & & \\
Male & 107 & 53.50 \\
Female & 93 & 46.50 \\
Occupation & & \\
Student & 16 & 8.00 \\
Service & 52 & 26.00 \\
Business & 57 & 28.50 \\
Housewife & 75 & 37.50 \\
Education & & \\
Below higher secondary & 46 & 23.00 \\
Higher secondary & 46 & 23.00 \\
Graduate & 60 & 30.00 \\
Postgraduate & 27 & 23.50 \\
Any other & 21 & 10.50 \\
\hline
\end{tabular}

Table 2. Participants' perceptions on value of different avenues of awareness

\begin{tabular}{|c|c|c|c|c|c|c|}
\hline- & $\begin{array}{l}\begin{array}{l}\text { Point-of-purchase } \\
\text { display }\end{array} \\
\end{array}$ & $\begin{array}{l}\text { Retailer } \\
\text { recommendation }\end{array}$ & $\begin{array}{l}\text { Friends and } \\
\text { relatives }\end{array}$ & Advertisements & Newspapers/magazines & $\begin{array}{l}\text { Promotional } \\
\text { Campaigns }\end{array}$ \\
\hline \multicolumn{7}{|l|}{ Rice } \\
\hline Mean & 3.28 & 3.07 & 3.41 & 2.16 & 1.35 & 1.68 \\
\hline SD & 1.24 & 1.58 & 1.23 & 1.02 & .72 & .72 \\
\hline Sample & 180 & 180 & 180 & 180 & 180 & 180 \\
\hline \multicolumn{7}{|l|}{ Sugar } \\
\hline Mean & 3.37 & 3.03 & 3.47 & 2.34 & 1.39 & 1.78 \\
\hline SD & 1.27 & 1.62 & 1.23 & 1.07 & .74 & .88 \\
\hline Sample & 103 & 103 & 103 & 103 & 103 & 103 \\
\hline
\end{tabular}

Table 3. Participants' attitudes towards branded sugar/rice parameter

\begin{tabular}{|c|c|c|c|c|c|c|c|c|c|}
\hline & $\begin{array}{l}\text { It is more } \\
\text { nutritious } \\
\text { than } \\
\text { unbranded } \\
\text { rice }\end{array}$ & $\begin{array}{l}\text { It has } \\
\text { better } \\
\text { taste/flavor } \\
\text { than } \\
\text { unbranded } \\
\text { rice }\end{array}$ & $\begin{array}{l}\text { It is free } \\
\text { from } \\
\text { adulterants }\end{array}$ & $\begin{array}{l}\text { It is a } \\
\text { quality } \\
\text { certified } \\
\text { product }\end{array}$ & $\begin{array}{l}\text { Using } \\
\text { branded } \\
\text { rice } \\
\text { enhances } \\
\text { my social } \\
\text { status }\end{array}$ & $\begin{array}{l}\text { It is } \\
\text { over } \\
\text { priced }\end{array}$ & $\begin{array}{l}\text { It is free } \\
\text { from } \\
\text { insecticides/ } \\
\text { pesticides } \\
\text { and harmful } \\
\text { chemicals }\end{array}$ & $\begin{array}{l}\text { It is } \\
\text { easily } \\
\text { available } \\
\text { near my } \\
\text { home }\end{array}$ & $\begin{array}{l}\text { Its } \\
\text { packaging } \\
\text { is easy } \\
\text { handle }\end{array}$ \\
\hline \multicolumn{10}{|l|}{ Rice } \\
\hline Mean & 0.55 & 0.60 & 1.38 & 0.62 & 0.85 & -0.35 & 1.37 & 0.10 & -1.08 \\
\hline SD & 0.99 & 0.94 & 0.68 & 0.96 & 1.17 & 1.33 & 0.70 & 1.29 & 1.20 \\
\hline Sample & 180 & 180 & 180 & 180 & 180 & 180 & 180 & 180 & 180 \\
\hline \multicolumn{10}{|l|}{ Sugar } \\
\hline Mean & 0.67 & 0.72 & 1.48 & 0.70 & 0.92 & -0.53 & 1.46 & -0.04 & -0.95 \\
\hline $\mathrm{SD}$ & 0.98 & 0.82 & 0.50 & 0.91 & 1.14 & 1.31 & 0.55 & 1.23 & 1.26 \\
\hline Sample & 103 & 103 & 103 & 103 & 103 & 103 & 103 & 103 & 103 \\
\hline
\end{tabular}


Table 4. Variance analysis of Participants' attitudes towards branded rice parameters based on demographics

\begin{tabular}{lllll}
\hline Parameter & \multicolumn{3}{l}{ Branded rice } \\
\cline { 2 - 5 } & Age & Gender & Education & income \\
\hline It is more nutritious than unbranded rice & 1.648 & 0.135 & 0.965 & 6.55 \\
It has better taste/flavor than unbranded rice & 0.844 & 0.894 & 0.768 & 6.93 \\
It is free from adulterants & 0.009 & 0.017 & 0.784 & 7.13 \\
It is a quality certified product & 0.436 & 1.795 & 1.810 & 44.91 \\
Using branded rice enhances my social status & 0.186 & 1.003 & 0.754 & 0.18 \\
It is over priced & 0.377 & 1.664 & 9.171 & 70.99 \\
It is free from insecticides/ pesticides and harmful chemicals & 0.419 & 0.032 & 0.798 & 8.98 \\
It is easily available near my home & 1.362 & 0.840 & 6.556 & 85.22 \\
Its packaging is easy handle & 1.699 & 1.796 & 3.128 & 11.63 \\
\hline
\end{tabular}
Note. ${ }^{*}$ Significance at $\mathrm{P}<0.05$.

Table 5. Variance analysis of Participants' attitudes towards branded sugar parameters based on demographics

\begin{tabular}{lllll}
\hline Parameter & \multicolumn{3}{l}{ Branded sugar } \\
\cline { 2 - 5 } & Age & Gender & Education & income \\
\hline It is more nutritious than unbranded sugar & 1.420 & 0.277 & 0.853 & 2.51 \\
It has better taste/flavor than unbranded sugar & 0.081 & 0.359 & 0.427 & 2.99 \\
It is free from adulterants & 0.241 & 0.108 & 1.115 & 0.69 \\
It is a quality certified product & 0.134 & 0.006 & 1.478 & 35.29 \\
Using branded rice enhances my social status & 0.058 & 1.013 & 2.535 & 0.15 \\
It is over priced & 0.675 & 0.129 & 5.451 & 37.70 \\
It is free from insecticides/ pesticides and harmful chemicals & 0.643 & 0.352 & 0.904 & 1.19 \\
It is easily available near my home & 0.970 & 0.099 & 3.418 & 42.30 \\
Its packaging is easy handle & 0.267 & 4.402 & 2.090 & 5.10 \\
\hline
\end{tabular}

Note. *Significance at $\mathrm{P}<0.05$.

Table 6. Issues affecting buying decisions for branded rice

\begin{tabular}{|c|c|c|c|c|c|c|c|c|c|c|c|c|}
\hline & Price & $\begin{array}{l}\text { Brand } \\
\text { image }\end{array}$ & $\begin{array}{l}\text { Easy } \\
\text { avail }\end{array}$ & $\begin{array}{l}\text { Attractive } \\
\text { display }\end{array}$ & $\begin{array}{l}\text { Retailer's } \\
\text { recomm }\end{array}$ & $\begin{array}{l}\text { References } \\
\text { from } \\
\text { friends/relatives }\end{array}$ & Packaging & $\begin{array}{l}\text { Availability } \\
\text { of } \\
\text { nutritional } \\
\text { information }\end{array}$ & $\begin{array}{l}\text { Info } \\
\text { about } \\
\text { the } \\
\text { expiry } \\
\text { date }\end{array}$ & $\begin{array}{l}\text { Customer } \\
\text { feedback } \\
\text { info }\end{array}$ & $\begin{array}{l}\text { Attractive } \\
\text { ads }\end{array}$ & $\begin{array}{l}\text { Value } \\
\text { money }\end{array}$ \\
\hline \multicolumn{13}{|l|}{ Rice } \\
\hline Mean & 3.34 & 3.08 & 3.33 & 2.15 & 3.00 & 4.05 & 2.31 & 2.69 & 1.48 & 1.10 & 2.27 & 3.72 \\
\hline SD & 0.88 & 1.06 & 0.50 & 0.53 & 0.76 & 0.72 & 0.56 & 0.63 & 0.53 & 0.31 & 0.71 & 0.63 \\
\hline Sample & 119 & 119 & 119 & 119 & 119 & 119 & 119 & 119 & 119 & 119 & 119 & 119 \\
\hline \multicolumn{13}{|l|}{ Sugar } \\
\hline Mean & 3.16 & 3.15 & 3.26 & 2.18 & 2.92 & 4.09 & 2.33 & 2.71 & 1.49 & 1.09 & 2.28 & 3.64 \\
\hline SD & 0.86 & 0.52 & 0.44 & 0.45 & 0.66 & 0.70 & 0.55 & 0.58 & 0.53 & 0.30 & 0.65 & 0.58 \\
\hline Sample & 71 & 71 & 71 & 71 & 71 & 71 & 71 & 71 & 71 & 71 & 71 & 71 \\
\hline
\end{tabular}

Table 7. Variance analysis of issues affecting buying decisions for branded rice based on demographics

\begin{tabular}{lllll}
\hline Factor & \multicolumn{3}{c}{ Branded rice } \\
\cline { 2 - 5 } & Age & Gender & Education & Income \\
\hline Price & 1.945 & 0.005 & 1.099 & $80.658^{*}$ \\
Brand image & 0.433 & 0.274 & $5.212^{*}$ & $137.686^{*}$ \\
Easy availability & 0.742 & 1.042 & $12.156^{*}$ & $11.851^{*}$ \\
Attractive display & 1.354 & 0.137 & $3.629^{*}$ & $8.809^{*}$ \\
Retailer's recommendation & 1.631 & 0.128 & 4.992 & $63.038^{*}$ \\
References from friends/relatives & 0.336 & 0.249 & 1.181 & 0.449 \\
Packaging & 0.199 & 0.003 & 0.128 & $6.565^{*}$ \\
Availability of nutritional information & 0.578 & 0.388 & 1.725 & $15.247^{*}$ \\
Information about the expiry date & 0.262 & 0.590 & 1.832 & 1.177 \\
Customer feedback information & 0.555 & $4.176^{*}$ & 1.630 & 1.266 \\
Attractive advertisements & 1.062 & 1.431 & 2.177 & 2.740 \\
Value money & 1.334 & 0.034 & 0.827 & $11.434^{*}$ \\
\hline
\end{tabular}

Note. * Significance at $\mathrm{P}<0.05$. 
Table 8. Variance analysis of issues affecting buying decisions for branded sugar on the basis of demographic

\begin{tabular}{lllll}
\hline \multirow{2}{*}{ Factor } & \multicolumn{3}{c}{ Branded rice } \\
\cline { 2 - 5 } & Age & Gender & Education & Income \\
\hline Price & 0.530 & 0.383 & 0.961 & $41.384^{*}$ \\
Brand image & 0.172 & 3.508 & $4.218^{*}$ & $71.774^{*}$ \\
Easy availability & 0.580 & 0.480 & $7.770^{*}$ & 3.141 \\
Attractive display & 0.415 & 3.121 & 2.402 & 2.465 \\
Retailer's recommendation & 0.935 & 1.931 & $2.698^{*}$ & $28.114^{*}$ \\
References from friends/relatives & 0.256 & 0.000 & 1.916 & 0.095 \\
Packaging & 0.309 & 0.420 & 0.303 & 1.942 \\
Availability of nutritional information & 0.697 & 0.262 & 0.795 & $11.334^{*}$ \\
Information about expiry date & 0.351 & 2.882 & 1.506 & 0.151 \\
Information regarding customers feedback & 0.499 & 0.753 & 0.921 & 1.249 \\
Attractive advertisements & 0.235 & 1.418 & 1.815 & 0.857 \\
Value money & 1.467 & 1.589 & 0.943 & $7.229^{*}$ \\
& & & & \\
\hline
\end{tabular}

Note. *Significance at $\mathrm{P}<0.05$.

Table 9. Major parameters affecting buying decisions for branded sugar/rice

\begin{tabular}{lllll}
\hline & \multicolumn{2}{l}{ BRANDED RICE (n=119) } & \multicolumn{2}{l}{ BRANDED SUGAR (n=71) } \\
\cline { 2 - 5 } & Mean & SD & Mean & SD \\
\hline Taste including flavor/aroma & 4.61 & 0.55 & 4.63 & 0.54 \\
Nutrition & 4.61 & 0.55 & 4.61 & 0.56 \\
Free from adulterants & 4.61 & 0.55 & 4.61 & 0.56 \\
Free from harmful chemicals & 4.63 & 0.55 & 4.63 & 0.56 \\
\hline
\end{tabular}

\section{Limitations and Future Directions}

For the scale of this research the study couldn't take into account other types of marked products specially ones that are considered Egyptian specialist such as halawa and white cheese, they type of information resulting from that would really help as a guide of branding strategies.

\section{References}

Aaker, D. A. (1996b). Measuring brand equity across products and markets. California Management Review, 38(3), 102-120. https://doi.org/10.2307/41165845

Ajzen, I. (1991). Theory of planned behavior. Organization Behavior and Human Decision Process, 50(2), 179-211. https://doi.org/10.1016/0749-5978(91)90020-T

Ajzen, I. (2001). Nature and operation of attitudes. Annual Review of Psychology, 52, $27-58$. https://doi.org/10.1146/annurev.psych.52.1.27

Ajzen, I., \& Fishbein, M. (2008). Scaling and testing multiplicative combinations in the expectancy-value model of attitudes. Journal of Applied Social Psychology, 38(9), 2222-2247. https://doi.org/10.1111/j.1559-1816.2008.00389.x

Akgungor, S., Miran, B., \& Abay, C. (2010). Consumer willingness to pay for organic food in urban Turkey. Journal of International Food \& Agribusiness Marketing, 22(3-4), 299-313. https://doi.org/10.1080/08974431003641455

Alam, S. S., \& Sayuti, N. M. (2011). Applying the Theory of Planned Behavior (TPB) in halal food purchasing. International Journal of Commerce and Management, 21(1), 8-20. https://doi.org/10.1108/10569211111111676

Anderson, J. R. (1983). The Architecture of Cognition. Cambridge, MA: Harvard University Press.

Bareham, J. (1995). Consumer Behaviour in the Food Industry: A European Perspective. Oxford: Butterworth Heineman.

Cerjak, M., Kovacic, D., \& Grgic, I. (2011). What are the concerns of Croatian traditional food consumers regarding GM food? British Food Journal, 113(1), 37-49. https://doi.org/10.1108/00070701111097321

Chabiri, S. A., Hati, S. S., Dimari, G. A., \& Ogugbuaja, V. O. (2009). Comparative quality assessment of branded and unbranded edible vegetable oils in Nigeria. The Pacific Journal of Science and Technology, 10(2), 927-934. 
Chen, M. F. (2009). Attitude toward organic foods among Taiwanese as related to health consciousness, environmental attitudes, and the mediating effects of a healthy lifestyle. British Food Journal, 111(2), 165-178. https://doi.org/10.1108/00070700910931986

Chernatony, L. (1996). The brand management odyssey. Journal of General Management, 21(4), 35-37. https://doi.org/10.1177/030630709602100402

Dean, M., Raats, M. M., \& Shepherd, R. (2008). Moral concerns and consumer choice of fresh and processed organic foods. Journal of Applied Social Psychology, 38(8), 2088-2107. https://doi.org/10.1111/j.1559-1816.2008.00382.x

Dhar, R., \& Wertenbroch, K. (2000). Consumer choice between hedonic and utilitarian goods. Journal of Marketing Research, 37(1), 60-71. https://doi.org/10.1509/jmkr.37.1.60.18718

Dolak, D. (2005). How to Brand and Market a Commodity. Retrieved from http://www.brandchannel.com/papers_reviews.asp?sp_id $=570$.

Espejel, J., Fandos, C., \& Flavián, C. (2008). The influence of consumer degree of knowledge on consumer behavior, the case of Spanish olive oil. Journal of Food Products Marketing, 15(1), 15-37. https://doi.org/10.1080/10454440802470565

Feldwick, P. (2002). What is Brand Equity, Anyway? Admap Publications, Henley-on-Thames.

Felzensztein, C., Hibbert, S., \& Vong, G. (2004). Is the country of origin the fifth element in the marketing mix of imported wine? Journal of Food Products Marketing, 10(4), 73-84. https://doi.org/10.1300/J038v10n04_05

Fishbein, M., \& Ajzen, I. (1975). Belief, Attitude, Intention, and Behaviour: An Introduction to Theory and Research. New York, NY: J. Wiley \& Sons.

GAIN. (2017) Global agricultural information network report 2017, Egypt, retail food. Retrieved July 3, 2018, from https://gain.fas.usda.gov/Recent\%20GAIN\%20Publications/Retail\%20Foods_Cairo_Egypt_12-21-2017.pdf

Ghodeswar, B. M. (2008). Building brand identity in competitive markets: a conceptual model. Journal of Product \& Brand Management, 17(1), 4-12. https://doi.org/10.1108/10610420810856468

Grunert, K. G., Bech-Larsen, T., \& Bredahl, L. (2000). Three issues in consumer quality perception and acceptance of dairy products. International Dairy Journal, 10(8), 575-584. https://doi.org/10.1016/S0958-6946(00)00085-6

Hankinson \& Cowking. (1995). What do you really mean by a brand? Journal of Brand Management, 3(1), 43-50. https://doi.org/10.1057/bm.1995.29

Hatirli, S. A., Ozkan, B., \& Aktas, A. R. (2004). Factors affecting fluid milk purchasing sources in Turkey. Food Quality and Preference, 15(6), 509-515. https://doi.org/10.1016/j.foodqual.2003.11.002

Hogg, A., \& Kalafatis, S. (1992). Current trends in the United Kingdom market for rice. Proceedings of the Prospects for Rice Consumption in Europe Symposium. October 24, Verona.

Ilyas, F., \& Javed, S., (2018). Service Quality and Satisfaction in Healthcare Sector of Pakistan - The Patients' Expectations. International Journal of Health Care Quality Assurance, 31(6), 489-501. https://doi.org/10.1108/IJHCQA-08-2016-0110

Jang, N., Dickerson, K. G., \& Hawley, J. M. (2005). Apparel product development: measures of apparel product success and failure. Journal of Fashion Marketing and Management, 9(2), 195-206. https://doi.org/10.1108/13612020510599349

Javed, S. A., \& Javed, S. (2015). The impact of product's packaging color on customers' buying preferences under time pressure. Marketing and Branding Research, 2(1), 4-14. https://doi.org/10.33844/mbr.2015.60293

Johnson, M. D., \& Gustafsson, A. (2000). Improving Customer Satisfaction, Loyalty, and Profit: An Integrated Measurement and Management System., University of Michigan Business School Management Series, Jossey-Bass, San Francisco, CA.

Johnson, M. D., Gustafsson, A., Andreassen, T. W., Lervik, L., \& Cha, J. (2001). The evolution and future of national customer satisfaction index models. Journal of Economic Psychology, 22(2), 217-245. https://doi.org/10.1016/S0167-4870(01)00030-7 
Juric, B., \& Worsley, A. (1998). Consumers' attitudes towards imported food products. Food Quality and Preference, 9(6), 431-441. https://doi.org/10.1016/S0950-3293(98)00027-5

Kapferer, J. N. (1997). Strategic Brand Management. London: Kogan-Page.

Keller, K. L. (2003). Brand synthesis: the multidimensionality of brand knowledge. Journal of Consumer Research, 29(4), 595-600. https://doi.org/10.1086/346254

Kotler, P. (1994). Marketing Management-analysis, Planning, Implementation, and Control (8th ed.). Prentice Hall.

Lassar, W., Mittal, B., \& Sharma, A. (1995). Measuring customer-based brand equity. Journal of Consumer Marketing, 12(4), 11-19. https://doi.org/10.1108/07363769510095270

Lau, G. T., \& Lee, S. H. (2000). Consumer's Trust in a Brand and the Link to Brand Loyalty. Journal of Market Focused Management, 4, 341-370. https://doi.org/10.1023/A:1009886520142

Lin, Alex Y.-S., Yu-Ting, H., \& Meng-Kai, L. (2015). Customer-Based Brand Equity: The Evidence from China. Contemporary Management Research Pages, 11(1), 75-94. https://doi.org/10.7903/cmr.14153

Liu, S. F. (2019). Bidirectional Absolute GRA/GIA model for Uncertain Systems: Application in Project Management. IEEE Access. Retrieved May 1, 2018, from https://ieeexplore.ieee.org/document/8666121

Lodorfos, G. N., \& Dennis, J. (2008). Consumers' intent: in the organic food market. Journal of Food Products Marketing, 14(2), 17-38. https://doi.org/10.1080/10454440801918218

Markovina, J., Cacic, J., Kljusuric, J. G., \& Kovacic, D. (2011). Young consumers' perception of functional foods in Croatia. British Food Journal, 113(1), 7-16. https://doi.org/10.1108/00070701111097303

Mohan, K. L., \& Gill, P. (2013). Purchase of branded commodity food products: empirical evidence from India. British Food Journal, 115(9), 1255-1280. https://doi.org/10.1108/BFJ-08-2011-0209

Montgomery, C. A., \& Wernerfelt, B. (1992). Risk reduction and umbrella branding. Journal of Business, 65(1), 31-50. https://doi.org/10.1086/296556

Muellera, S., \& Szolnoki, G. (2010). Wine packaging and labelling - do they impact market price? A hedonic price analysis of US scanner data. Refereed paper 5th International Academy of Wine Business Research Conference, 8-10 Feb 2010 Auckland (NZ).

Noor, N., Don A. K., \& Cassidy. (2016). Factors affecting halal food purchasing by non-Muslims in a multicultural society: a case study in Singapore. International Journal Islamic Marketing and Branding, l(4). https://doi.org/10.1504/IJIMB.2016.081315

Orth, U. R., McDaniel, M., Shellhammer, T., \& Lopetcharat, K. (2004). Promoting brand benefits: the role of consumer psychographics and lifestyle. Journal of Consumer Marketing, 21(2), 97-108. https://doi.org/10.1108/07363760410525669

Park, C. W., Jaworski, B. J., \& Macinnis, D. J. (1986). Strategic brand concept-image management. Journal of Marketing, 50, 135-145. https://doi.org/10.1177/002224298605000401

Rimal, A., Fletcher, S. M., McWatters, K. H., Misra, S. K., \& Doedhar, S. (2001). Perception of food safety and changes in food consumption habits: a consumer analysis. International Journal of Consumer Studies, 25(1), 43-52. https://doi.org/10.1111/j.1470-6431.2001.00162.x

Rust, Roland, T. R., Zeithaml, V. A., \& Lemon, N. K. (2000). Driving Customer Equity: How Customer Lifetime Value Is Reshaping Corporate Strategy. New York: The Free Press.

Sifeng, L., \& Saad, A. J. (2018). Predicting the Research Output/Growth of Selected Countries: Application of Even GM (1, 1) and NDGM Models. Scientometrics, 115(1), 395-413. https://doi.org/10.1007/s11192-017-2586-5

Silayoi, P., \& Speece, M. (2004). Packaging and purchase decision: an exploratory study on the impact of involvement level and time pressure. British Food Journal, 106(8), 607-628. https://doi.org/10.1108/00070700410553602

Smith, R. E., \& Wright, W. F. (2004). Determinants of customer loyalty and financial performance. Journal of Management Accounting Research, 16(1), 183-205. https://doi.org/10.2308/jmar.2004.16.1.183

Tikkanen, I., \& Vaariskoski, M. (2010). Attributes and benefits of branded bread: case Artesaani. British Food Journal, 112(9), 1033-1043. https://doi.org/10.1108/00070701011074381 
Tsiotsou, R. (2006). The role of perceived product quality and overall satisfaction on purchase intentions. $\begin{array}{lllll}\text { International Journal of } & \text { Consumer }\end{array}$ https://doi.org/10.1111/j.1470-6431.2005.00477.x

Urban, J., Zverinova, I., \& Scasny, M. (2012). What motivates Czech consumers to buy organic food? Sociology Casopis, 48(3), 709-736.

USDA (United States Department of Agriculture). (2018). Egypt: update to Egypt's rice production, consumption and trade figures. Retrieved June 13, 2018, from https://www.fas.usda.gov/data/egypt-update-egypt-s-rice-production-consumption-and-trade-figuresUtami, H. D. (2010). Factors influencing consumer purchasing decision toward Malang meatballs at East Java Indonesia. Journal of Food Products Marketing, 17(1), 25-45. https://doi.org/10.1080/10454446.2011.532375

Vabo, M., \& Håvard, H. H. (2014). The Relationship between Food Preferences and Food Choice: A Theoretical Discussion. International Journal of Business and Social Science, 5(7), June.

Vermeir, I., \& Wim Verbeke, W. (2008). Sustainable food consumption among young adults in Belgium: Theory of planned behaviour and the role of confidence and values, Ecological Economics, 64(3), 542-553. https://doi.org/10.1016/j.ecolecon.2007.03.007

Wang, B. (2019). World GDP Forecasts for 2030. Retrieved May 20, 2018, from https://www.nextbigfuture.com/2019/01/world-gdp-forecasts-for-2030.html

Wang, E. S-T. (2010). Impact of multiple perceived value on consumers' brand preference and purchase intention: a case of snack foods. Journal of Food Products Marketing, 16(4), 386-397. https://doi.org/10.1080/10454446.2010.509242

Watanabe, Y., Suziki, N., \& Kaiser, H. M. (1999). Predicting Japanese dairy consumption behavior using $\begin{array}{lllll}\text { qualitative } & \text { survey } & \text { data. }\end{array}$ https://doi.org/10.1002/(SICI)1520-6297(199924)15:1<71::AID-AGR5>3.0.CO;2-H

Wolff, N. (2015). Luxe Laundry Is Actually a Thing. [online] DuJour. Retrieved May 24, 2018, from http://dujour.com/cities/laundress-soho-new-york-city-store-opening/

Yan, R. (2010). Product brand differentiation and dual - channel store performances of a multi - channel retailer. European Journal of Marketing, 44(5), 672-692. https://doi.org/10.1108/03090561011032324

Yeung, R. M. W., \& Morris, J. (2001). Food safety risk: consumer perception and purchase behavior. British Food Journal, 103(3), 170-186. https://doi.org/10.1108/00070700110386728

Zeithaml, V. A. (1988). Consumer perceptions of price, quality and value: a means-end model and synthesis of evidence. Journal of Marketing, 52, 2-22. https://doi.org/10.1177/002224298805200302

\section{Copyrights}

Copyright for this article is retained by the author, with first publication rights granted to the journal.

This is an open-access article distributed under the terms and conditions of the Creative Commons Attribution license (http://creativecommons.org/licenses/by/4.0/). 